\title{
Assessment of manual paddy transplanters for drudgery reduction of farm women in Mayurbhanj district of Odisha
}

\author{
JHUNILATA BHUYAN AND DEEPAK KUMAR MOHANTY
}

Received: 10.04.2017; Revised: 23.09.2017; Accepted: 09.10.2017

See end of the paper for authors' affiliations JHUNILATA BHUYAN

Krishi Vigyan Kendra, Mayurbhanj-1, SHAMAKHUNTA (ODISHA) INDIA

Email : jhuni.chutki@gmail.com
ABSTRACT : Transplanting of paddy is very tedious job mostly done by female workers. Manual hand transplanting consumes a lot of energy, time and fatigue, but the poor socioeconomic condition of the farmers does not allow them to adopt power operated transplanter. Different manual transplanters have been developed by different research centres as 2 row, 3 row and 4 row paddy transplanter. Keeping this in view KVK, Mayurbhanj-1 has undertaken OFT on different transplanters in drudgery aspect and compared with manual transplanting. Seven female subjects were selected in the age group 17-45years in the farmer's field. The mean value of age, weight, height, $\mathrm{VO}_{2}$ max and body surface area was found to be 29.1 years, $50.7 \mathrm{~kg}$, $152.5 \mathrm{~cm}, 1.68 \mathrm{l} / \mathrm{min}$ and $1.49 \mathrm{~m}^{2}$. The mean value of working heart rate was observed to be maximum of 130.6 beats/min in 3 row paddy transplanter followed by 126.7 beats/min in 2 row transplanter and 112.4 beats/min in local transplanting, respectively. The Oxygen consumption rate and relative cost of workload were observed to be maximum $1.01 \mathrm{l} / \mathrm{min}$ and 59.6 per cent in 3 row transplanter followed by $0.8 \mathrm{l} / \mathrm{min}$ and 57.8 per cent in 2 row transplanter and lowest in local practices, i.e. $0.5 \mathrm{l} / \mathrm{min}$ and 33.4 per cent. The field capacity was observed to be maximum 0.066 ha/day in 3 row transplanter followed by 0.03 and 0.054 ha/day in 2 row and local method of transplanting. The 3 row paddy transplanter was observed to be the best among all manual operated paddy transplanters.

KEY WORDS: Transplanter, Working heart rate, Oxygen consumption rate, Relative cost of workload

- HOW TO CITE THIS PAPER : Bhuyan, Jhunilata and Mohanty, Deepak Kumar (2017). Assessment of manual paddy transplanters for drudgery reduction of farm women in Mayurbhanj district of Odisha. Asian J. Home Sci., 12 (2) : 373-377, DOI: 10.15740/HAS/AJHS/12.2/373-377. 